\section{GEOCHRONOMETRY AND GEOLOGY} Radiometric Dating for Geologists

Edited by E. I. Hamilton and R. M. Farquhar. Pp. vii + 506. (Wiley (Interscience): London and New York, July 1968.) 147s.

Atтempts to date geological materials by means of their included "radiometric clocks" began soon after Becquerel's discovery of natural radioactivity. Between 1907, when Boltwood used lead, thorium and uranium analyses to estimate the ages of minerals, and the application of the mass spectrographic technique for isotope analysis by Nier in 1939, progress was slow because there was no way of making sufficiently accurate measurements of the quantities involved. Since 1950, and particularly during this decade, dramatic advances in instrumentation and greatly improved chemical procedures have led to geochronology becoming one of the most active fields in planetary science. The very rapidity with which knowledge is growing has inevitably resulted in contradiction and controversy between individual researchers and research schools. While this can be stimulating to workers within the field, the average geologist or geophysicist who wants to know the age of a particular rock or mineral certainly does not find it helpful. The root cause of the controversy is no longer on the analytical side, but arises from the immense practical difficulties inherent in the application of geochronometry to ancient rocks and minerals of complex rather than simple geological history. In this situation, textbooks on geochronology may become out of date almost before publication, and in current literature thero is no comprehensive account of the methods now available for the resolution of specific geological dating problems. The editors of Radiometric Dating for Geologists have attempted to fill this gap by gathering in one volume a series of modern accounts of the methods by which rocks and minerals can be dated, each accompanied by case histories of their practical application presented in as full a geological and geophysical context as possible.

On the whole, the book does live up to the editors' intentions. and will undoubtedly be of great value to non-specialists. The majority of the individual papers are excellent and directly to the point. There are the inevitable omissions arising from the book being overtaken by the rapid advance of research: perhaps the most important is the absence of any account of the new ${ }^{40} \mathrm{Ar} /$ ${ }^{39} \mathrm{Ar}$ total degassing and ${ }^{40} \mathrm{Ar} /{ }^{30} \mathrm{Ar}$ age spectrum methods which have revolutionized potassium-argon dating. Occasionally, the reader may be disconcerted by the contrary viewpoints of authors-such as the opposed statements regarding amphiboles on pages 16 and 139 - but undoubtedly the overall impression gained is that the application of geochronometry to geological problems is at last becoming a comprehensible seience rather than appcaring to the outsider to be some form of "black art". In addition, the volume contains indications of more general interest to geologists, often arising independently in the work of more than one contributor. Theso include, for example, a growing realization of the importance of metasomatism in rock paragenesis, even far away from areas in which it is an obvious feature, and a mounting volume of geochronological evidence which favours a return to a concept of episodic crustal development after the style of Stille.

Frank Fitch

\section{PLEISTOCENE STUDIES}

Pleistocene Geology and Biology

With Especial Reference to the British Isles. By R. G. West. Pp. xiii $+377+16$ plates. (Longmans: London, July 1968.) $63 s$.

Pleistocene studies have emerged recently as one of the most fruitful fields for investigation through an interdisciplinary approach. Thus it is not surprising to find a botanist writing a volume which ranges from Pleistocene biology to stratigraphy. A readable and up to date text has been long overdue in this field as a counterweight to the two volumes of Charlesworth, 1957 (of which, oddly, no mention is made in the references). West's book is prepared with that attention to detail which one would expect to follow from his numerous papers on glacial and interglacial sediments in East Anglia.

The format of the volume might justifiably be called "off-beat". Having progressed through the deposits and landforms typical of ice, glaciers and glacial geology (forty-one pages), in chapter four the author assigns a mere fourteen pages to non-glacial, principally biogenic, sediments before turning to a detailed treatment of the periglacial zone. Similarly, after further chapters on stratigraphical and biological investigations the pendulum swings back in chapter eight to the processes of internal and external origin which control the morphology and deposits associated with relative changes of sea level.

This somewhat uneven treatment presumably mirrors West's particular interests and gives to the book a singularly personal stamp.

Most of the chapters dealing with geomorphological processes, although clear and well illustrated, lack somewhat in depth. Third year undergraduates studying geology and geography, for whom the volume is partly intended, may have only slight interest in these sections. The chapter on the periglacial zone, however, gives an excellent review of recent continental literature and the formation of characteristic cryoturbate structures and patterns is analysed in considerable detail.

In the following chapters, chronology (a particularly clear exposition), climatic change and the bases for stratigraphical subdivision of Pleistocene deposits all receive brief coverage. It is in chapters twelve and thirteen, however, on Pleistocene stratigraphy and the history of Pleistocene flora and fauna in the British Isles, that the book makes its principal contribution.

Because of the space consumed in early chapters by the geomorphological background only some fifty-seven pages are concerned with the British Pleistocene. When it is noted that West's principal hunting ground in East Anglia occupies ten pages, the Midlands six pages, Wales and Northern England (one page each), Scotland (two pages), Ireland (four pages) and the rest of Britain plus general considerations (eighteen pages), it can be seen that page limitation has resulted in a rather superficial treatment of many Pleistocene problems. This is in part made good by a very full list of references.

The final fifty-six pages review the biological history of Britain during the Pleistocene and deal largely with palaeobotanical studies to which West has made such significant contributions during the past fifteen years.

In general, the second half of the volume distils the essence of the British Pleistocene, but rather too frequently leaves one with a faint aroma of the period rather than a knowledge of all its ingredients and the problems surrounding their admixture. The value of the book lies in providing for the first time under one cover a concise Pleistocene biology for the geologist and conversely the rudiments of Pleistocene geology for the biologist.

\section{W. W. Bishop}

\section{BEYOND THE TREE LINE}

\section{Arctic and Alpine Environments}

Vol. 10. Edited by H. E. Wright, jun., and W. H. Osburn. (Proceedings of the VII Congress of the International Association for Quaternary Research, Boulder-Denver, Colorado, August 14-September 19, 1965.) Pp. xii +308. (Indiana University Press: Bloomington and London, July 1968.) $119 s$. 